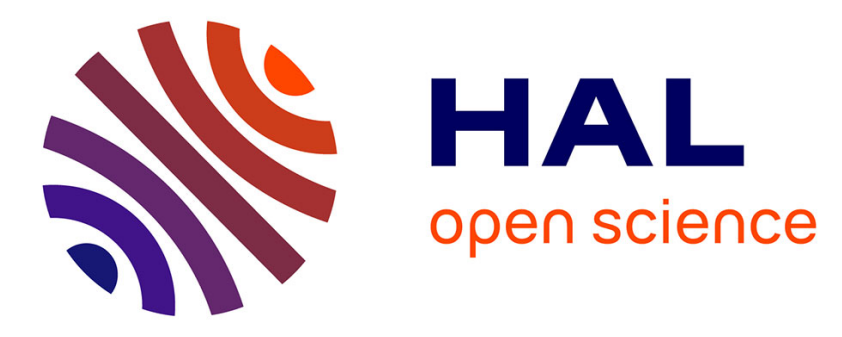

\title{
Development of a robust and efficient biogas processor for hydrogen production. Part 1: Modelling and simulation
}

Y Camacho, S Bensaid, S Lorentzou, N Vlachos, G Pantoleontos, A Konstandopoulos, M Luneau, F Meunier, N Guilhaume, Y. Schuurman, et al.

\section{To cite this version:}

Y Camacho, S Bensaid, S Lorentzou, N Vlachos, G Pantoleontos, et al.. Development of a robust and efficient biogas processor for hydrogen production. Part 1: Modelling and simulation. International Journal of Hydrogen Energy, 2017, 42 (36), pp.22841-22855. 10.1016/j.ijhydene.2017.07.147 . hal01625636

\section{HAL Id: hal-01625636 \\ https://hal.science/hal-01625636}

Submitted on 26 Jul 2021

HAL is a multi-disciplinary open access archive for the deposit and dissemination of scientific research documents, whether they are published or not. The documents may come from teaching and research institutions in France or abroad, or from public or private research centers.
L'archive ouverte pluridisciplinaire HAL, est destinée au dépôt et à la diffusion de documents scientifiques de niveau recherche, publiés ou non, émanant des établissements d'enseignement et de recherche français ou étrangers, des laboratoires publics ou privés.

\section{(c)(1)}

Distributed under a Creative Commons Attribution| 4.0 International License 


\title{
Development of a robust and efficient biogas processor for hydrogen production. Part 1: Modelling and simulation
}

\author{
Y.S. Montenegro Camacho ${ }^{\mathrm{a}}$, S. Bensaid ${ }^{\mathrm{a}}$, S. Lorentzou ${ }^{\mathrm{b}}, \mathbf{N}$. Vlachos ${ }^{\mathrm{b}}$, G. \\ Pantoleontos $^{\mathrm{b}}$, A. Konstandopoulos ${ }^{\mathrm{b}}$, M. Luneau ${ }^{\mathrm{c}}$, F.C. Meunier ${ }^{\mathrm{c}}, \mathbf{N}$. \\ Guilhaume $^{\text {c }}$, Y. Schuurman ${ }^{\text {c }}$, E. Werzner ${ }^{d}$, A. Herrmann ${ }^{d}$, F. Rau ${ }^{d}$, H. \\ Krause $^{d}$, E. Rezaei ${ }^{e}$, A. Ortona ${ }^{e}$, S. Gianella ${ }^{\text {f }}$, A. Khinsky ${ }^{g}$, \\ M. Antonini ${ }^{\text {h }}$, L. Marchisio h, F. Vilardo h, D. Trimis ${ }^{\text {, }}$, D. Fino ${ }^{a,{ }^{*}}$
}

a Politecnico di Torino, Corso Duca Degli Abruzzi 24, Torino, 10129, Italy

b Aerosol \& Particle Technology Laboratory (CERTH-CPERI), 6 Th Km Charilaou e Thermis, PO BOX 60361,570 01, Thermi, Thessaloniki, Greece

c Université de Lyon, Institut de Recherches sur La Catalyse et L'Environnement de Lyon, IRCELYON UMR5256 CNRS, 2 Avenue Albert Einstein, F-69626, Villeurbanne Cedex, France

d Institute of Thermal Engineering, Technische Universit€at Bergakademie Freiberg, Gustave Zeuner Straße 7, 09596,

Freiberg, Sachsen, Germany

e ICIMSI, SUPSI, Galleria 2, CH-6928, Manno, Switzerland

f Erbicol SA, Viale Pereda 21, CH6228, Balerna, Switzerland

g Amiagus, Savanoriu Str. 290, LT-49473, Kaunas, Lithuania

h Hysytech Srl, Strada Del Drosso, 33/18, Torino, Italy

i Karlsruhe Institute of Technology, Engler-Bunte-Institute, Engler-Bunte-Ring 7, 76131, Karlsruhe, Germany

\begin{abstract}
The present work deals with the modelling and simulation of a biogas Demo-processor for green hydrogen production via Autothermal reforming (ATR) process aimed at covering a wide span of potential applications, from fuel cells feed up to the production of pure hydrogen. The biogas ATR unit is composed of a structured catalyst support close coupled to a wall-flow filter that retain soot particles that can be formed during the ATR reaction. Modelling and simulation (CFD and FEM) were carried out to select the innovative catalyst support with promising results for the fuel processor. 3D digital sample reconstruction was performed for the selection of the appropriate porous structures commercially available for the soot filtration and furthermore, 2D CFD analysis was also used to examine flow uniformity issues due to soot trap integration downstream to the ATR. Moreover, the inherent flexibility of the model performed allowed its application in the assessment of the Demonstration plant operating in real conditions. Besides, Aspen simulation has demonstrated that the ATR process is the most promising process to hydrogen production compared to other types of reforming process.
\end{abstract}

\footnotetext{
* Corresponding author.

E-mail address: debora.fino@polito.it (D. Fino).
} 


\section{Introduction}

Biogas is a renewable source of methane, it is produced from the anaerobic digestion of organic matter and is mainly composed of methane $\left(\mathrm{CH}_{4}\right)$ and carbon dioxide $\left(\mathrm{CO}_{2}\right)$ and minor species such as hydrogen sulphide, ammonia, humidity, etc. [1,2]. Biogas can be directly used as a combustible; however, the combustion process of biogas to generate heat has a low efficiency, because the humidity and $\mathrm{CO}_{2}$ content decrease the calorific value of the fuel $[3,4]$. Biogas can be converted into hydrogen-rich syngas via catalytic reforming process for fuel cell application [3]. Hydrogen is a promising energy carrier with high energy capacity and zero carbon content [5-7]. The reforming process for hydrogen production are: dry reforming (DR), steam reforming (SR), catalytic partial oxidation (CPOX), and auto thermal reforming (ATR) process, according to the following Reactions (R1-R4), respectively.

$$
\begin{aligned}
& \mathrm{CH}_{4}+\mathrm{CO}_{2} \leftrightarrow 2 \mathrm{CO}+2 \mathrm{H}_{2} \quad \Delta \mathrm{H}=+247 \mathrm{~kJ} / \mathrm{mol} \\
& \mathrm{CH}_{4}+\mathrm{H}_{2} \mathrm{O} \leftrightarrow \mathrm{CO}+3 \mathrm{H}_{2} \quad \Delta \mathrm{H}=+206,2 \mathrm{~kJ} / \mathrm{mol} \\
& \mathrm{CH}_{4}+\frac{1}{2} \mathrm{O}_{2} \rightarrow \mathrm{CO}+2 \mathrm{H}_{2} \quad \Delta \mathrm{H}=-36 \mathrm{~kJ} / \mathrm{mol} \\
& \mathrm{CH}_{4}+\frac{1}{2} \mathrm{xO}_{2}+\mathrm{yCO}_{2}+(1-\mathrm{x}-\mathrm{y}) \mathrm{H}_{2} \mathrm{O} \leftrightarrow(\mathrm{y}+1) \mathrm{CO} \\
& +(3-\mathrm{x}-\mathrm{y}) \mathrm{H}_{2}
\end{aligned}
$$

$\mathrm{H}_{2} \mathrm{O}+\mathrm{CO} \leftrightarrow \mathrm{CO}_{2}+\mathrm{H}_{2} \quad \Delta \mathrm{H}=-41,2 \mathrm{~kJ} / \mathrm{mol}$

DR occurs when methane reacts with carbon dioxide to produce carbon monoxide and hydrogen (R1). This reaction is strongly endothermic, since it transforms two stable molecules $\left(\mathrm{CH}_{4}\right.$ and $\left.\mathrm{CO}_{2}\right)$, into syngas, which is a reactive and high value product, used as raw material for other processes. It occurs at high temperatures $\left(800-1000{ }^{\circ} \mathrm{C}\right)$ [8]. The water-gas shift Reaction ( $\mathrm{R} 5$ ) is boosted at high $\mathrm{CO}_{2}$ concentration, reducing the $\mathrm{H}_{2} / \mathrm{CO}$ ratio to values less than one between $400{ }^{\circ} \mathrm{C}$ and $800{ }^{\circ} \mathrm{C}$. Other undesired reactions taking place in $\mathrm{DR}$ are the Boudouard Reaction (R6), CO reduction (R7) and $\mathrm{CH}_{4}$ decomposition (R8), which produce carbon and reduce the selectivity to syngas [9].

$2 \mathrm{CO} \leftrightarrow \mathrm{C}+\mathrm{CO}_{2} \quad \Delta \mathrm{H}=-172 \mathrm{~kJ} / \mathrm{mol}$

$\mathrm{CO}+\mathrm{H}_{2} \leftrightarrow \mathrm{C}+\mathrm{H}_{2} \mathrm{O} \quad \Delta \mathrm{H}=-131 \mathrm{~kJ} / \mathrm{mol}$

$\mathrm{CH}_{4} \leftrightarrow \mathrm{C}+2 \mathrm{H}_{2} \quad \Delta \mathrm{H}=+75 \mathrm{~kJ} / \mathrm{mol}$

The SR (R2) is a highly endothermic process, which requires reaction temperatures between 650 and $850^{\circ} \mathrm{C}$ and low pressures to accomplish maximum methane conversion [10]. The $\mathrm{H}_{2} / \mathrm{CO}$ ratio is equal to three, being the most suitable reforming process due to its high $\mathrm{H}_{2}$ production. The reforming reaction causes a continuous temperature decrease, thus, requiring a continuous external source of heat, provided by the combustion of additional methane and/or from using the available energy in the separated exhaust stream through combustion or simple heat exchange.
In the CPOX process, methane is partially oxidized at atmospheric pressure in lack of oxygen to produce syngas with an $\mathrm{H}_{2} / \mathrm{CO}$ ratio close to 2. This Reaction (R3), is moderately exothermic and requires temperatures between 700 and $900{ }^{\circ} \mathrm{C}$ to guarantee complete methane conversion and to decrease the soot formation [11].

The biogas ATR process is a combination of the endothermic (SR) and exothermic (CPOX) reactions, the last provides the energy needed for the endothermic reforming reactions [5]. The economies of scale (much larger stream units are possible) and more compact sizes of equipment are the main advantages of the ATR compared to SR process $[12,13]$. Furthermore, other advantages of ATR of biogas concern the presence of water, which increases hydrogen yield and reduces the sensitivity to soot or carbon depositions in long term operation, good adaptability to changing biogas composition, compact design, efficient handling of heat, lower materials costs, the speed for ending or starting the reactor, the capacity to produce a higher amount of $\mathrm{H}_{2}$ with a lower $\mathrm{O}_{2}$ consumption, an easier process control and the highest efficiency $[6,14]$.

In a catalytic reforming process, great attention must be dedicated to the catalyst support (e.g. powder, pellets, honeycomb, foams, etc.), because it can greatly affect the reactor performances, whether in steady state at high space velocity (in terms of conversion and selectivity), or the reactor dynamic response especially during light-off [15]. Then, due to the severe operating conditions (high temperature and high flow rates), heat and mass transfer properties play an important role in the behavior of the short contact time. Several authors have reported that the use of cellular material support improve the coupling of exothermic and endothermic reaction in methane reforming [15-19]. Foams and honeycomb monolith catalyst supports structured are the most used for syngas production [13]. Foam structured catalysts allow a higher activity with respect to honeycomb structured catalysts as well as a lower average temperature along the catalytic bed and a more uniform temperature profile, due to the better conductive heat along the catalytic monolith [19]. Ceramic foams have important properties for catalytic activity such as low pressure drop, high thermal stability and enhanced heat transfer, in particular when materials with high thermal conductivity are employed [20].

According to Palma et al. [20], high thermal conductivity supports consent a flat thermal profile along catalytic bed, and thus a higher average temperature at the outlet of the catalytic bed, allowing higher methane conversion [21]. On the one hand, highly conductive supports reduce the hot-spot formation and the temperature peak of the exothermal combustion zone at the catalytic bed reactor inlet in ATR process; in the other side, high thermal conductivity materials guarantee a more uniform radial temperature [21].

Silicon carbide ( $\mathrm{SiC}$ ) has excellent thermal conductivity, high chemical stability, high mechanical strength and high thermal shock resistance, that means that SiC can withstand manufacturing stresses better, and therefore make it flexible and suitable for all shapes and sizes of catalyst supports [22]. These properties are required to be a potential heterogeneous catalyst support candidate, especially for high endothermic and/or exothermic reactions [23]. Silicon carbide can be 
manufactured in several different forms including, among others, sintered $\mathrm{SiC}$, recrystallized $\mathrm{SiC}$ and silicon infiltrated $\mathrm{SiC}$ (SiSiC). Silicon carbide can also be present in several crystal structures, of which two of the most popular are $\alpha$-SiC and $\beta$-SiC. Erbicol's process to manufacture SiSiC ceramics is based on the reactive silicon infiltration of a preform containing $\alpha$-SiC and carbon [24-26]. SiSiC is particularly interesting due to its outstanding mechanical and thermal properties at high temperatures. The $\mathrm{Si}-\mathrm{SiC}$ microstructure has already proven to withstand severe high temperature oxidizing conditions [25]. Moreover, SiSiC porous periodic architectures have recently been produced using replica technique of lattice structures obtained from polymeric templates made by $3 \mathrm{D}$ printing followed by reactive infiltration of silicon $[25,26]$.

$\mathrm{SiC}$ wall-flow honeycomb monolithic structures are used for the removal of soot particles and are considered an essential component of the exhaust of diesel engines $[27,28]$. The wall-flow filters are ceramic porous structures that consist of many parallel channels of rectangular cross section, with the adjacent channels alternately plugged [29]. The gas stream that enters an open channel is forced to pass through the porous wall of the channels. The particles inside the gaseous stream are trapped inside and on the top of the wall of the channel, whereas the gases exit from the adjacent channel free of particles.

A novel application of such filters is implemented within the scope of this work. A key innovation in this study is the adaptation of a wall-flow filter close coupled to the ATR reactor, which could entail effective filtration and conversion of any soot like particles eventually generated by heterohomogeneous reactions in the inlet part of the ATR reactor during normal operation or due to the decomposition of traces of incomplete reforming products.

The present work deals with the modelling and simulation of a biogas processor for green hydrogen production via ATR process. The study comprises the ATR structured support design, the 3D digital reconstruction of a soot filter and the 2D CFD analysis to examine the flow uniformity issues due to soot trap integration downstream to the ATR. Within this study, new and innovative supports for biogas ATR were designed, in order to identify a suitable support structure, which are based on high thermal conductivity cellular materials to disperse the heat axially in the reactor, which meets the desired demands, i.e. high effective thermal conductivity, open structure to avoid dead zones and plugging by soot build up, strong mixing and high contact time of the fluid with the catalytic surface, high mechanical strength and low pressure drop. Instead, the support for the removal of potential carbonaceous materials were commercially investigated.

\section{Materials and methods}

\section{Biogas reforming process modelling}

In order to design a biogas processor to produce $50 \mathrm{Nm}^{3} / \mathrm{h}$ of hydrogen, simulations using Aspen plus were performed. The process efficiency depends on the biogas reforming route, the level of heat integration, and the preheating temperature of the mixed reactants, the steam-to-carbon (S/C) and oxygento-carbon $(\mathrm{O} / \mathrm{C})$ ratio as well as the usage of the off-gas from pressure swing adsorption (PSA).

Model biogas composed of clean methane and carbon dioxide (60:40 vol:vol) was used in this study.

The energetic performance of ATR, SR and CPOX reforming systems was evaluated by the thermal efficiency and is calculated as the energy output divided by the energy input [30], as shown in Eq. (1):

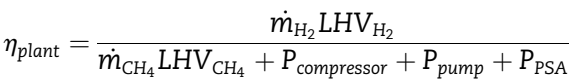

where $\dot{m}_{i}$ and $L H V_{i}$ are the mass flow and the Lower Heating Value of species "i", respectively; $P_{i}$ is the electrical power of component "i" shown in Fig. 5.

As above mentioned, an important benefit of the ATR process is the inherent flexibility of the system itself; in fact, modifying the temperature, $\mathrm{O} / \mathrm{C}$ and $\mathrm{S} / \mathrm{C}$ ratios, it is possible to achieve an auto-thermal operation. In the same way, the final composition depends of the values of these variables [31]. The effect of the temperature, S/C and O/C ratio on the efficiency plant for biogas ATR process was investigated. The ratios are defined as following:

$\frac{\mathrm{S}}{\mathrm{C}}=\frac{\dot{\mathrm{n}}_{\mathrm{H}_{2} \mathrm{O}}}{\dot{\mathrm{n}}_{\mathrm{CH}_{4}}}$

$\frac{\mathrm{O}}{\mathrm{C}}=\frac{2^{*} n_{\mathrm{O}_{2}}}{\dot{n}_{\mathrm{CH}_{4}}}$

The S/C ratio was changed from 1.5 to 5 , the O/C from 0.8 to 1.3 and the reactant pre-heating temperature from $500{ }^{\circ} \mathrm{C}$ to $700{ }^{\circ} \mathrm{C}$.

\section{Numerical model of the structured catalyst supports for ATR reactor}

New catalyst structures based on high thermal conductivity cellular materials have been designed, which promote a transient or even turbulent flow inside the catalyst support, which enhances the transport of the species due to hydrodynamic dispersion. Advantages arising from this are an improved conversion efficiency but also a more reliable operation, since the increased mixing prevents the formation of hot spots as it homogenizes the distribution of the gas components and helps to spread locally released heat more rapidly due to convection. Main advantages of the homogeneous lattice based design arise out of the repetitive unit cells that allow full characterization of the lattice and its effective properties by analysing a single unit cell assuming periodicity in all directions.

Homogenous lattices composed of Cubic, Octet and Kelvin cells with a fixed porosity of $\varepsilon=0.85$ and cylindrically shaped struts, as shown in Table 1, were selected for the present study. Besides, the conventional random foam was examined for comparison. Numerical simulations based on CFD and FEM models have been performed on the different geometries, which are assessed by different effective properties.

Due to the fixed porosity, strut diameter $(d)$ and specific surface area $(S)$ of the structures scale with the edge length of the single unit cell (LC) as defined follows [32]: 
Table 1 - Catalyst support geometries.

\begin{tabular}{lllll} 
Cubic lattice (100) & Cubic lattice (111) (Rotated Cube) & Modified Octet Cell & Kelvin cell \\
\hline & & &
\end{tabular}

$d[m]=a L_{c}$

$S\left[\frac{m^{2}}{m^{3}}\right]=\frac{b}{L_{c}}$

where the factors $\mathrm{a}$ and $\mathrm{b}$ are specific dimensionless constants of each geometry as listed in Table 2 .

Heat transfer

The effective thermal conductivity (ETC) in absence of the fluid indicates, how well the structures are able to spread heat, e.g. from local hot spots. In order to numerically predict the ETC, the averaged Fouriers law of heat conduction (Eq. 6) is applied to a unit cell of the homogenous lattice [33].

$\dot{q}_{a v}^{\prime \prime}=k_{e f f} \frac{T_{h}-T_{c}}{L}$

where $L$ is the distance between hot and cold boundaries those are maintained at temperatures $T_{h}$ and $T_{c}$, respectively. $K_{\text {eff }}$ is the effective thermal conductivity and $\dot{q}_{a v}^{\prime \prime}$ is the average steady-state heat flux in the X-direction for an applied temperature difference $T_{h}-T_{c}\left(T_{h}>T_{c}\right)$ in direction $X$. The remaining four boundaries are assumed to be adiabatic in order to ensure one-dimensional heat transfer in an averaged sense [34].

For the solution of Eq. (6), one requires solving the steadystate heat transfer for pure conduction in order to predict the temperature distribution within the porous medium and hence to calculate $\dot{q}_{a v}^{\prime \prime}$. The effective thermal conductivity of the structures was evaluated as described by Mendes et al. [33]. The heat transfer was solved by using the finite volume method (FVM) under the assumption of a non-conducting fluid phase.

Hydrodynamic dispersion coefficient

The transient flow field within the computational domain was obtained from the solution of the governing equations for

Table 2 - Geometric properties of the different unit cell models [32].

\begin{tabular}{lllll} 
& $\begin{array}{c}\text { Cube } \\
\text { cell }\end{array}$ & $\begin{array}{c}\text { Octet } \\
\text { cell }\end{array}$ & $\begin{array}{c}\text { Kelvin } \\
\text { cell }\end{array}$ & $\begin{array}{c}\text { Conventional } \\
\text { foam }\end{array}$ \\
\hline Porosity & 0,85 & 0,85 & 0,85 & 0,86 \\
$\mathrm{a}$ & 0,28 & 0,14 & 0,17 & - \\
$\mathrm{b}$ & 1,9578 & 3,8166 & 3,1782 & 3,2250 \\
\hline
\end{tabular}

mass and momentum, which were numerically solved using a CFD code based on the Lattice Boltzmann Method (LBM) $[35,36]$.

\section{Mechanical strength}

In order to test the mechanical behavior of the supports made of SiSiC lattice structures (with $\mathrm{E}=264 \mathrm{GPa}$, density $\rho=2640 \mathrm{~kg} / \mathrm{m}^{3}$ and poisson's ratio $v=0.25$ ), an analysis on the basis of the finite element method (FEM) was performed employing the commercial software COMSOL V4.4. For generation of the lattice structures each strut has been modeled by two vertices and a connection between them using MATLAB. The structure was loaded by giving a tensile displacement of $0.01 \mathrm{~mm}$ to the upper vertices to determine the maximum stress.

For the thermal and fluid flow simulations, the different geometries are numerically modeled using Cartesian voxel approximations, where each voxel is either attributed to be solid or liquid. In the present work, the computational domain is resolved with a resolution of $256^{3}$ voxels, which was found to be sufficient for grid-independent solutions [37].

\section{Pressure drop}

The numerical simulations were accompanied by a series of pressure drop experiments in air. The in-house setup, mainly consists of the mass flow controller, a duct with square cross section of $52 \times 52 \mathrm{~mm}$ and sensors for the measurement of inlet pressure, differential pressure, temperature as well as mass flow. It allows the testing of samples with a length of up to $100 \mathrm{~mm}$. For this investigation, 3D printed lattice structures of cubic, octet and Kelvin cells with 7 elements along each dimension of size $L=7.43 \mathrm{~mm}$, were tested. For the octet cells lattice, due to the anisotropy of its structure, two different orientations of the specimen were tested. The experiments were performed for different velocities ranging from 1 to $6 \mathrm{~m} / \mathrm{s}$ (cross-sectional average before the fluid enters the porous structure) at ambient conditions.

\section{Wall-flow soot filter 3-D digital sample reconstructed (microstructure computations)}

The steps that were followed for the selection of the appropriate porous structures, for the removal of potential carbonaceous materials that may be produced during the ATR reactions, were similar to the development of the support 
structures for the reforming catalyst, however they were focused not in creating a new structure but investigating the suitability of commercially available structures. Initially digital representations of candidate materials were reconstructed taking into account filter material characteristics (pore or grain size, porosity, wall thickness) that are commercially available to predetermine suitable material parameters on the basis of resistance to the flow and filtration efficiency. The methodology for the aforementioned process for digital materials reconstruction was previously reported in detail in Refs. [38,39]. The model framework employed in this effort consists of a set of tools encompassing the following functionality: i) digital microstructure reconstruction of porous wall samples via process-mimetic methods, ii) calculation of gas flow through the digital porous wall sample, and iii) simulation of particle capture by the digital porous wall sample.

The main objective of the resolved microstructure computations was to guide the selection of a suitable material. SiC was chosen as the material to be used in the specific application since it is commercially available and it has several advantages, such as high thermal conductivity and mechanical strength. The main parameters which characterize the SiC filter material and which must be determined are: wall thickness, porosity and grain size. These parameters directly affect pressure drop and filtration efficiency of the bare (uncoated) filter material. In view of the additional role of the particle trap as a substrate for catalytic post-treatment of the reformate, the selection of material porosity needs to also account for the pore space needed for the catalytic coatings.

To investigate the microstructure of the filter segments and obtain the required data for the digital material reconstruction conducted, Scanning Electron Microscopy (SEM) was employed (Fig. 1). More specifically, monolith samples were cut in the vertical and horizontal direction to obtain sectional images. The monolith segments were impregnated in resin in a suitable-sized mould to achieve a flat, well-polished surface for high quality imaging. Sequential images were acquired at a specific magnification so as to resolve the major (linear) features of interest by at least $20-40$ pixels. The size of area imaged for each material was guided by the requirement of capturing approx. $10 \times 10$ major material features (e.g. average pores) and was met by acquisition of multiple adjacent overlapping images and subsequent stitching in image processing software.

The digitally reconstructed sample (Fig. 2(a)) was subjected to calculation of fluid flow through the porous wall in order to determine the model filter wall permeability. The material geometry and the flow field are represented by spatial occupancy enumeration on a Cartesian grid with a resolution (grid cell size) of $0.5 \mu \mathrm{m}$. An explicit (based on Chorin's artificial compressibility scheme [40]) finite volume method is employed to solve for steady incompressible viscid flow. The flow field within the digital filter wall sample can be seen in Fig. 2(b) below.

The resolved microstructure framework described above was applied to a parametric study of pressure drop and filtration efficiency with respect to extruded filter wall thickness, $\mathrm{SiC}$ mean grain size and filter wall porosity. The filtration conditions at which the simulations are carried out
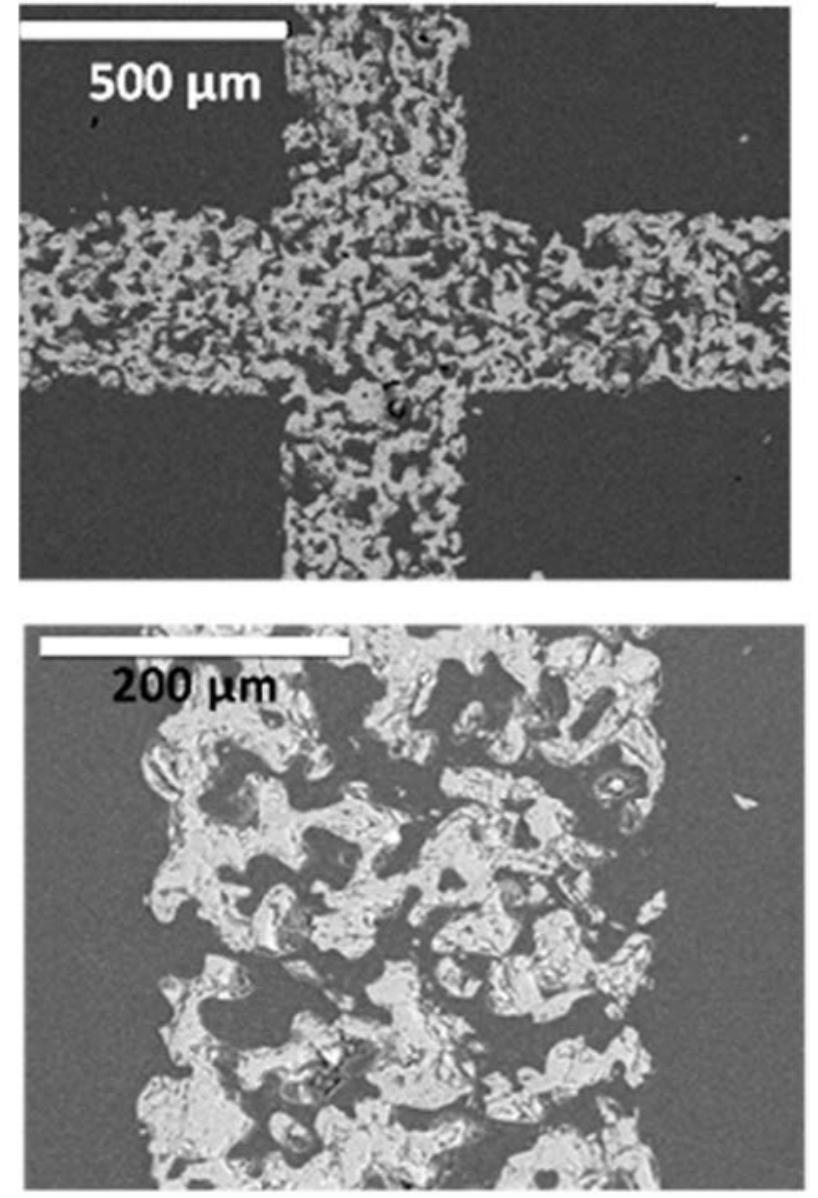

Fig. 1 - SEM image of the characteristic microstructure of a honeycomb monolith wall.

correspond to a reactor flow of $100 \mathrm{Nm}^{3} / \mathrm{hr}$ at $600^{\circ} \mathrm{C}$ with a $20 \mathrm{~L}$ monolith that has $1.5 \mathrm{~m}^{2} / \mathrm{L}$ of filtration area.

The carbonaceous particles in the filtration simulation are modeled by a nanoparticle geometry library, based on fractallike aggregate morphology consisting of 30-4000 primary particles. The range of mobility-equivalent diameter spanned from $30 \mathrm{~nm}$ to $800 \mathrm{~nm}$ over which the filtration behavior of the filter wall is expected to transition from the diffusion to the interception filtration regimes, i.e. the region of particle size expected to exhibit a minimum in filtration efficiency.

The parametric study considered extruded particle trap wall thickness $7-11 \mathrm{mil}(178 \mu \mathrm{m}-280 \mu \mathrm{m})$, porosity $0.4-0.55$ and average grain size $12 \mu \mathrm{m}-24 \mu \mathrm{m}$. These parameter spans were chosen on the basis of what is feasible/available from the state of the art in the manufacture of SiC extruded honeycomb filter monoliths.

The filters were evaluated in terms of: i) flow resistance (permeability), ii) filtration efficiency and iii) development of pressure drop during loading of carbonaceous materials.

\section{Flow resistance}

The measurement of flow resistance (permeability) was conducted in a dedicated rig consisting of a Mass Flow Controller (MFC), a specially manufactured filter holder, a high precision pressure transducer and a thermocouple. The gas used was air 


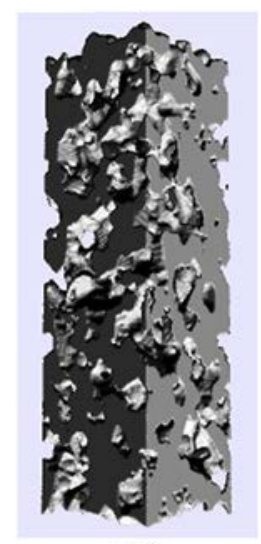

(a)

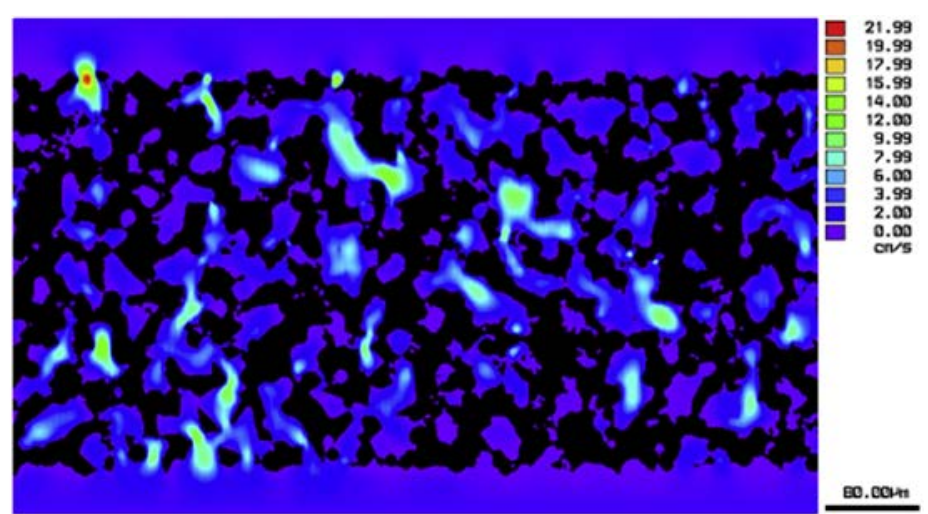

(b)

Fig. 2 - (a) Rendering of the digitally reconstructed 3-D porous wall sample and (b) visualisation of the flow velocity on a section through the porous wall sample and adjacent solution domain. The wall geometry is periodic in the directions normal to the filtration flow.

at ambient temperature. Gas flow was varied between 0 and $100 \mathrm{lpm}$ (100 lpm correspond to a filtration velocity of approximately $4.5 \mathrm{~cm} / \mathrm{s}$ ). For each set of permeability measurement twenty experimental points (pressure drop versus flow) were collected. The permeability, $\mathrm{k}\left(\mathrm{m}^{2}\right)$ of the filter sample is determined based on the following equation [41]:

$\Delta P_{\text {clean }}=\frac{\mu Q}{2 V_{\text {trap }}}\left(a+w_{s}\right)^{2}\left[\frac{w_{s}}{k a}+\frac{8 F L^{2}}{3 a^{4}}\right]+\frac{2 \zeta \rho Q^{2}\left(a+w_{s}\right)^{4}}{V_{\text {trap }}^{2} a^{2}}\left(\frac{L}{a}\right)^{2}$

where, $\Delta P_{\text {clean }}$ is the pressure drop across the filter, $a$ is the honeycomb filter cell size, $w_{s}$ is the filter wall thickness, $L$ is the filter outer length, $V_{\text {trap }}$ is the effective filter volume, $F$ is a factor equal to $28.454, Q$ is the volumetric air flow rate, $\mu$ is the dynamic viscosity of air, $\rho$ is the air density, $k$ is the filter wall permeability, and $\zeta$ is the contraction/expansion inertial losses coefficient.

\section{Filtration efficiency}

For the evaluation of the performance of the selected filters with respect to their clean filtration efficiency and pressure drop development during the loading with carbonaceous particles, a Combustion Aerosol Standard (CAST 2, Matter Engineering) soot particle generator was used to simulate the carbon particles formed from the combustion of gaseous hydrocarbons.

CAST generates soot aggregates with a monomodal, stable and repeatable mobility size distribution. Two CAST operating points were chosen - P1- corresponds to large primary particles (mean diameter $\mathrm{dp}=196 \mathrm{~nm}$ and P2- corresponds to small primary particles (mean diameter $d p=91 \mathrm{~nm}$ ) - for the loading of the monoliths with different size distribution of particles (simulants of expected reactor particles) and the evaluation of their filtration efficiency and pressure drop development. The exit of the CAST burner was connected to the inlet of a holder/reactor that contains the monolith for evaluation. Both in the case of the filtration efficiency, as well as for the loading, the experiments were conducted at room temperature, without additional heating of the monolith. In the case of the filtration efficiency measurements, the CAST was operated in the diluted mode (filtration velocity: $0.35 \mathrm{~cm}$ / s) in order to achieve particle concentration levels that are appropriate for particle measurements with a Scanning Mobility Particle Sizer (SMPS) coupled with a Concentration Particle Counter (CPC). The particle size distribution was measured upstream and downstream of the monolith; particles first pass through an impactor having a cut-off size above $1 \mu \mathrm{m}$, and then they are size-classified in a Differential Mobility Analyzer (DMA).

\section{Pressure drop}

In the case of the evaluation of the pressure drop during particle loading, there was no need for dilution of the CAST stream, and therefore the undiluted mode of operation of the CAST generator was used that allowed to achieve higher filtration velocities $(1.1-1.35 \mathrm{~cm} / \mathrm{s})$.

\section{Integration of the wall-flow filter}

The material properties that were derived from the preceding work were used for the implementation of suitable Computational Fluid Dynamics (CFD) models for the determination of the design for the integration of the filter in the ATR system. Since the filter can only provide axial flow because of its honeycomb structure and it is of much smaller diameter than the heat exchanger that follows, it is essential to investigate the degree of flow-spreading needed and the suitability of the proposed trap position with CFD simulation. The CFD calculation results must essentially confirm that the selected particle trap dimensions and position are acceptable in that they permit, with acceptable pressure drop penalty, the provision of uniform flow entry into the heat exchanger.

A 2D CFD analysis, with the ANSYS Fluent 15.0 software, was conducted in order to examine flow uniformity due to the filter incorporation downstream of the reforming catalyst. The integration focused on: a) the degree of flow uniformity required in the heat exchanger, since the filter displaces the originally present flow distributor plates, b) the stagnant flow space around the filter; c) mechanical fixation of the trap 
including rings and flanges, d) whether there is the need to secure the filter axially, and e) the requirement for being able to install and remove the filter from the top access of the ATR. The filter dimensions and placement determine the space available for including such a distributor plate.

The ANSYS CFD solvers are based on the finite volume method; the domains are discretized into a finite set of control volumes, for which general conservation (transport) equations for mass, momentum, and energy are solved. These balance equations include convective, dispersive and generation terms.

For the current study, the ATR reactor can be described in 2-D cylindrical coordinates formulation because there are no 3-D effects of interest in the flow field. Fig. 3 illustrates the axisymmetric sketch in the ANSYS Fluent environment, where symmetry boundary conditions (symmetry axis in Fig. 3), are applied, solid boundaries (type: "wall”) are imposed, and porous zones (black shaded areas) are formulated. The ATR reactor geometry is represented according to actual geometry up to the entry to the heat exchanger tubes. The porous zones representing a perforated distributor plate and a

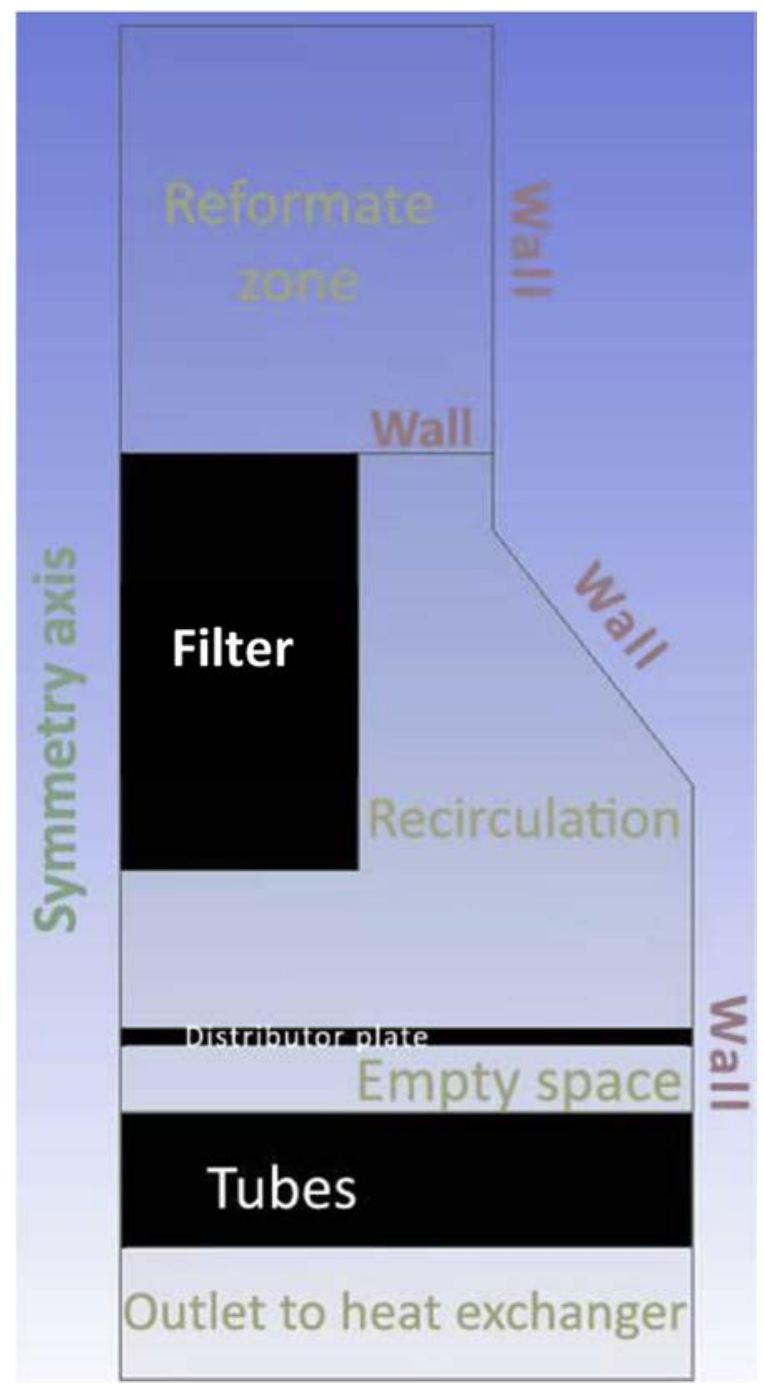

Fig. 3 - 2-D axisymmetric formulation for the ATR parts in ANSYS Fluent pre-processor. heat exchanger, downstream of the filter region, are not drawn to their actual size in the axial direction. The actual distributor plate thickness is varied during the investigation but the effect of this variation is included in the model via adjustment of the porous medium flow resistance in the Fluent geometry. Similarly, the full heat exchanger tube bank is not included in the model, nor is the tube bank geometry resolved. This porous zone (called: "Tubes" in the diagram of Fig. 3) is needed in order to represent the flow resistance characteristics of the tube bank and thereby provide realistic conditions for the flow field calculation further upstream. Software limitations do not permit placement of a domain outlet boundary adjacent to a porous zone, therefore an outlet region is also included.

The assumptions and features of this model are: a) isothermal operation, b) steady-state conditions, c) k- $\varepsilon$ RNG turbulence model and d) Fluent porous medium formulation. Details of the setting-up of the model are not presented in this work for space economy.

Three different cases were studied (related to the characteristics of the distributor plate located after the filter, i.e. actual hole pitch configurations, hole diameters and porosities-open area fraction of the plate) in order to assess the effect of the distributor plate resistance on the flow uniformity and the pressure drop.

\section{Results and discussion}

\section{Biogas reforming process modelling}

Fig. 4 (left) shows the effect of the S/C and O/C ratio on the efficiency plant for biogas ATR without using PSA off-gas at a reactant pre-heating temperature of $600{ }^{\circ} \mathrm{C}$. The plant efficiency decreases when the S/C ratio increase, despite of an increasing yield of hydrogen. For high S/C ratio the heat that is necessary for reactant preheating and steam generation, cannot be provided only by heat integration from the product gas cooling. Therefore, an additional external heat source would be required. Obtained results from Aspen Plus simulation (performed at affiliation d) mass and energy flow modelling have shown the positive effect of heat integration on the plant efficiencies. Fig. 4 (right) show that the highest efficiency equal to $65 \%$ (using $\mathrm{S} / \mathrm{C}=1.5$ and $\mathrm{O} / \mathrm{C}=1.02$ ) is achieved with an ATR process without using a PSA unit. Through the energetic usage of the PSA off-gas for steam generation and superheating, a plant efficiency of $69 \%$ is reached, due to the higher hydrogen yield in the synthetic gas resulting from an enhanced $\mathrm{S} / \mathrm{C}$ ratio.

Fig. 5 depicts the flow sheet of the hydrogen production process from autothermal reforming of biogas.

In the first step, there is the compression, pre-heating and mixing of air, steam and biogas. Then, the fed mixture is supported by a steam ejector, which operates with the superheated steam-air mixture.

The ejector replaces a biogas compressor with the advantages of a simple structure without mobile parts and low costs. The ejector has a double scope. The first one is the mixing of steam, air and biogas whereas the second one is the compression of the biogas without using a compressor. In the 

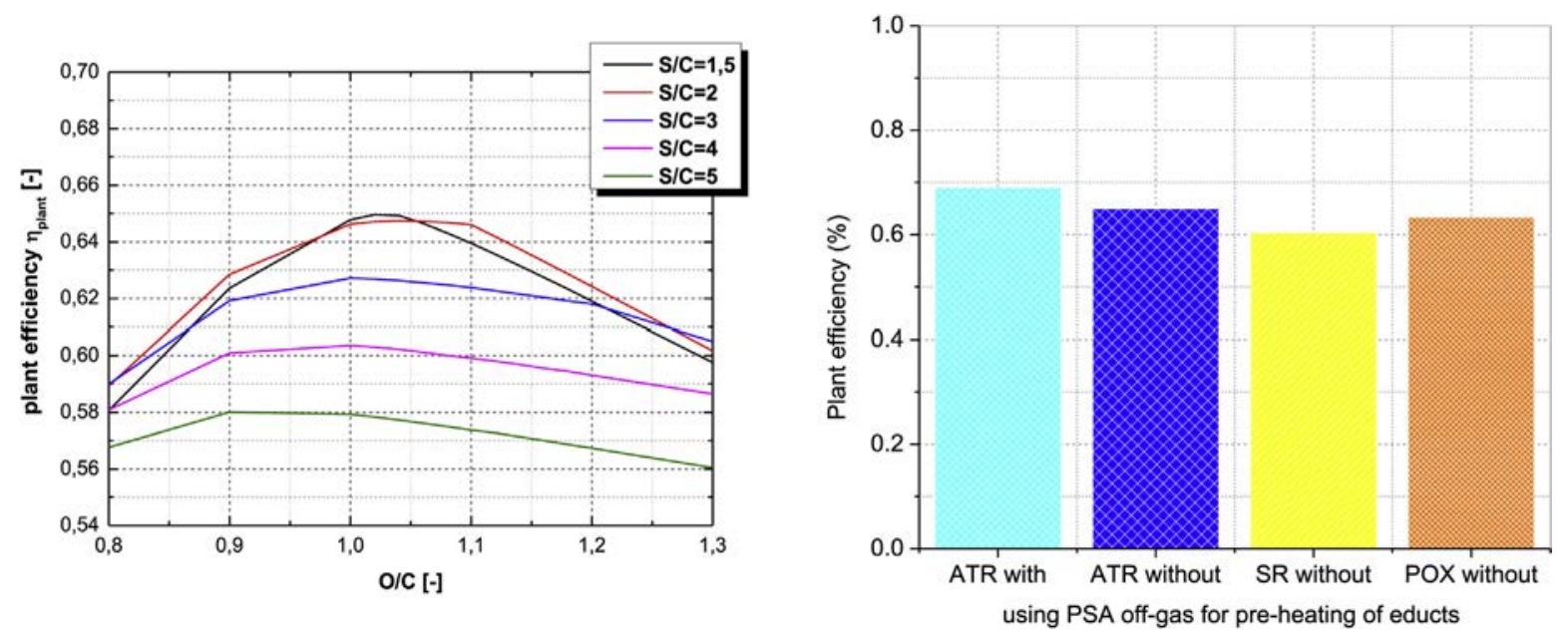

Fig. 4 - Maximum plant efficiency at different S/C and O/C ratio (left) and for different types of biogas reforming with maximum heat integration (right) [42].

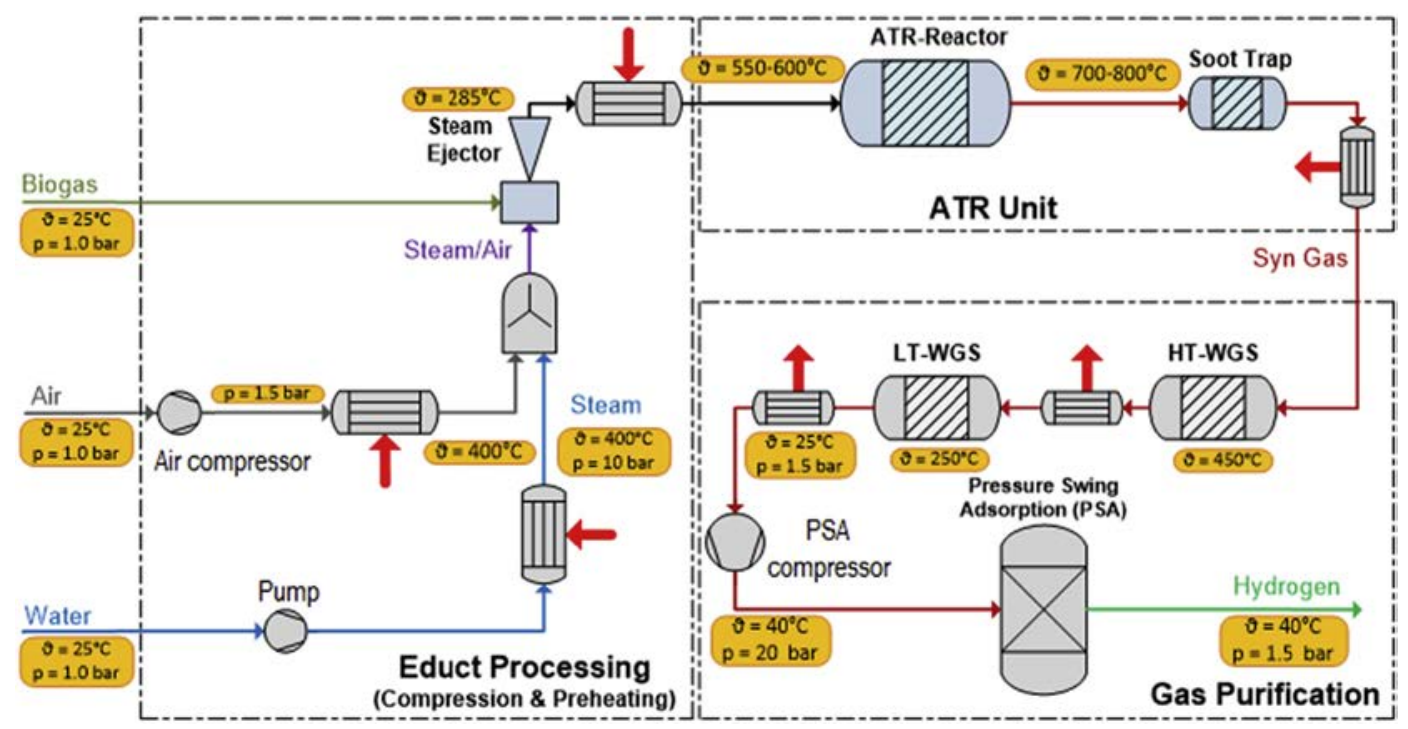

Fig. 5 - Flowsheet of the $\mathrm{H}_{2}$ production process from ATR of biogas [42-44].

second step, it takes place the catalytic conversion of the mixture to syngas in the ATR unit close coupled to a wall flow filter to retain the carbon particles produced. The last section consists of the gas purification with high and low-temperature water gas shift (HT-WGS and LT-WGS) reactors as well as a downstream pressure swing adsorption (PSA) unit [42-44].

\section{Numerical model of the structured catalyst supports for ATR reactor}

The idea with the use of structured catalyst support in biogas ATR reforming is to improve the coupling of exothermic and endothermic reactions as has been reported in literature $[19,45]$. The use of structured catalysts characterized by highly conductive materials can result in improving the heat transfer along the catalytic bed, affording high performance with a flattened radial temperature gradients [46]. So, identification of a suitable micro-structure for the catalyst support was based in which is less prone to hot spots. Then, the ideal supports should have high effective thermal conductivity, high transverse hydrodynamic dispersion and low longitudinal hydrodynamic dispersion, low pressure drop and high probability of fluid-wall contact.

Selected results from the simulations on the different lattice structures, are presented in Fig. 7 for pressure drop (Fig. 6 (left)) and transversal hydrodynamic dispersion (Fig. 6 (right)) properties.

The effective thermal conductivity indicates the ability of the structures to spread locally released heat and to avoid hot spots. The results have shown comparable performance of all structures.

Hydrodynamic dispersion is crucial for the catalytic conversion and can also prevent from hot spots [37]. As an indicator for the mixing performance of the different structures, the transverse and longitudinal dispersion coefficients have been evaluated for a range of different 
Reynolds numbers (Re), where Re is based on the size of a unit cell (Fig. 6).

The results of this comparative analysis between lattices with different cell types show on one side high mechanical strength of octet cells lattice and on the other side, relatively low strength of the Kelvin cell based lattice. Instead, for the cubic cell lattice the maximum mechanical stress resisted ranks in between the other structures.

Besides, the results have demonstrated that the lowest pressure drop is presented by the cubic cell lattice as illustrated in Fig. 6 (left).

The 3D-printed support structures were compared numerically regarding various hydrodynamic and thermodynamic properties. As shown in Fig. 6 (right) by means of the hydrodynamic dispersion, some of those lattices showed promising results when compared to a random ceramic foam. One can observe that there is: low dispersion at low Reynolds numbers due to laminar flow, significant increase of dispersion for the cubic lattice in flow direction (111) and good performance of random foam.
The results suggest a lattice composed of rotated cube cell as the most suitable catalyst support structure.

\section{Wall-flow soot filter 3-D digital sample reconstructed (microstructure computations)}

It can be seen from the pressure drop results ( $11 \mathrm{~mm}$ filter wall thickness and 12.6, 17 and $24.3 \mu \mathrm{m}$ grain sizes) in Fig. 7 (left), over this parameter space, that the pressure drop is most sensitive to porosity variation for the smaller grain diameters. In all cases the predicted pressure drop (due to the filter wall) remains at an acceptable level for the application in the ATR.

Although on a relative basis the filter wall pressure drop varies with respect to grain size, on an absolute basis the filter wall contribution to trap pressure drop is expected to be minor, to be overshadowed by channel flow friction losses and pressure drop from any coatings and particle deposits on the filter wall. Therefore, the focus turns to the filtration efficiency results shown in Fig. 7 (right) and Fig. 8. Here it can be seen that the variation of grain size again has the most
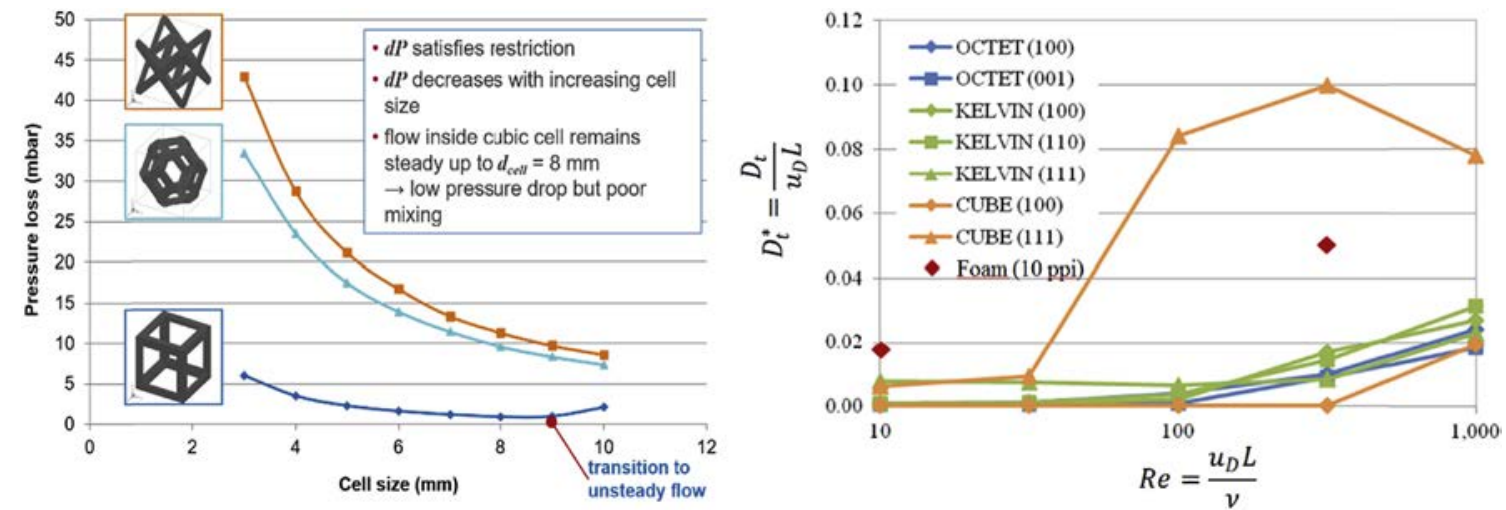

Fig. 6 - Pressure drop modelling evaluation (left) and relation of Reynolds number Re and transversal hydrodynamic dispersion $D^{*}{ }_{h, t .}$ (right).
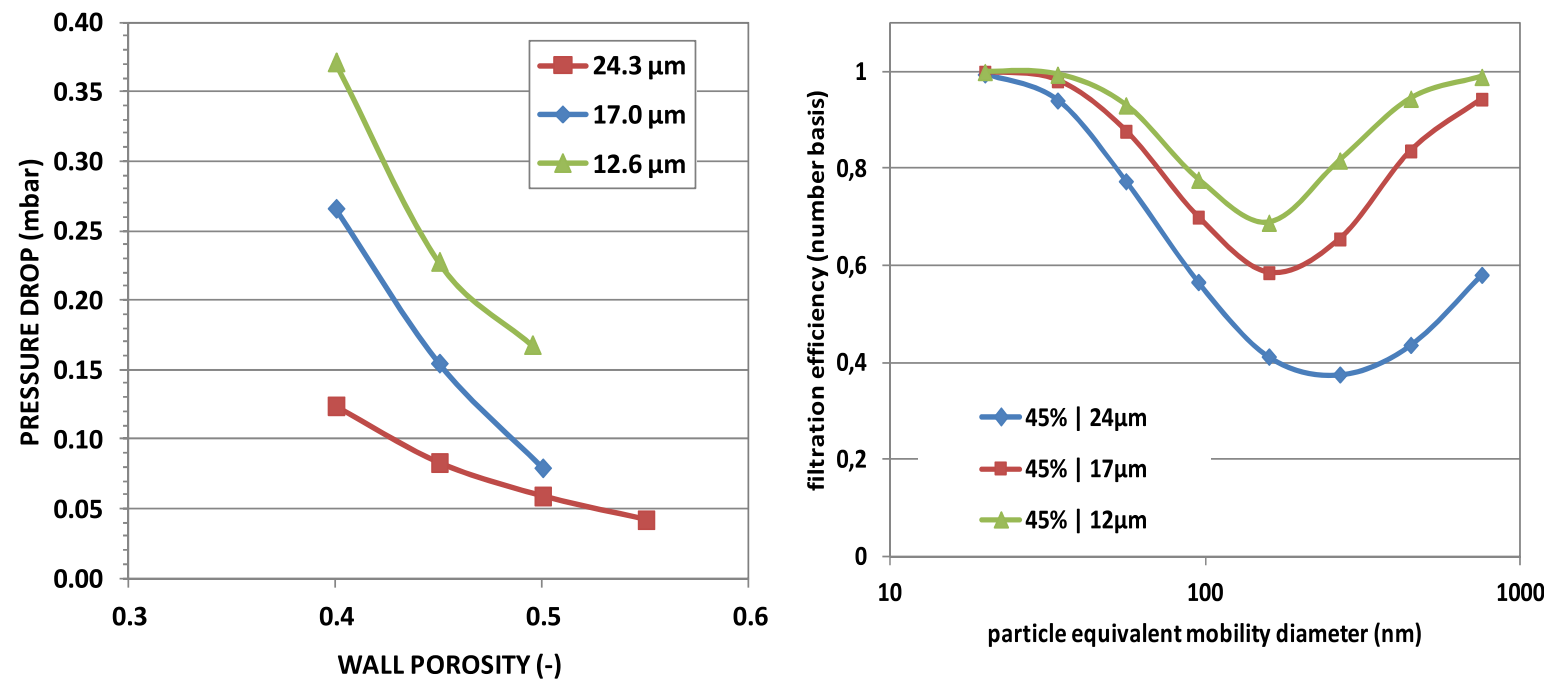

Fig. 7 - Results of filter wall pressure drop (11 mm filter wall thickness and 12.6, 17 and $24.3 \mu \mathrm{m}$ grain sizes) (left) and clean/ uncoated filtration efficiency (porosity constant at 0.45 and 12, 17 and 24 grain sizes) (right) from the parametric microstructure study for the particle trap material. 

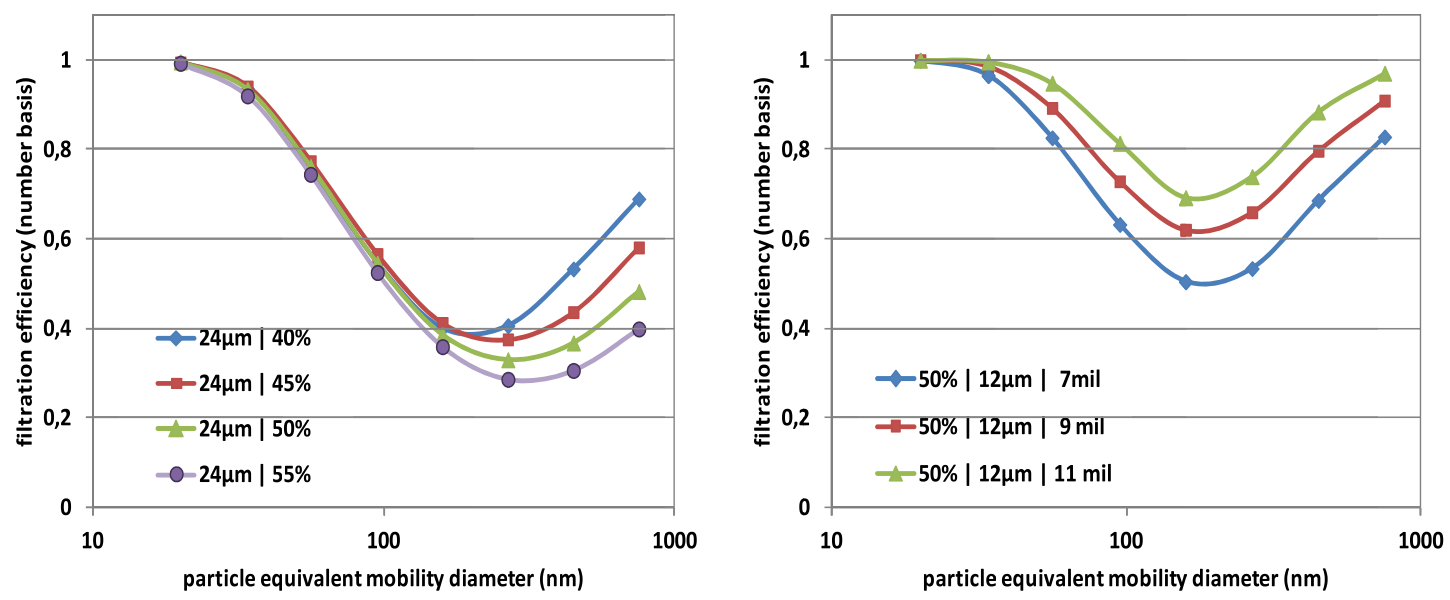

Fig. 8 - Filtration efficiency results of the parametric study at constant average grain size of $24 \mu \mathrm{m}$ and wall thickness of 11 mil (left) and at constant porosity of 0.50 and grain size of $12 \mu \mathrm{m}$ (right).

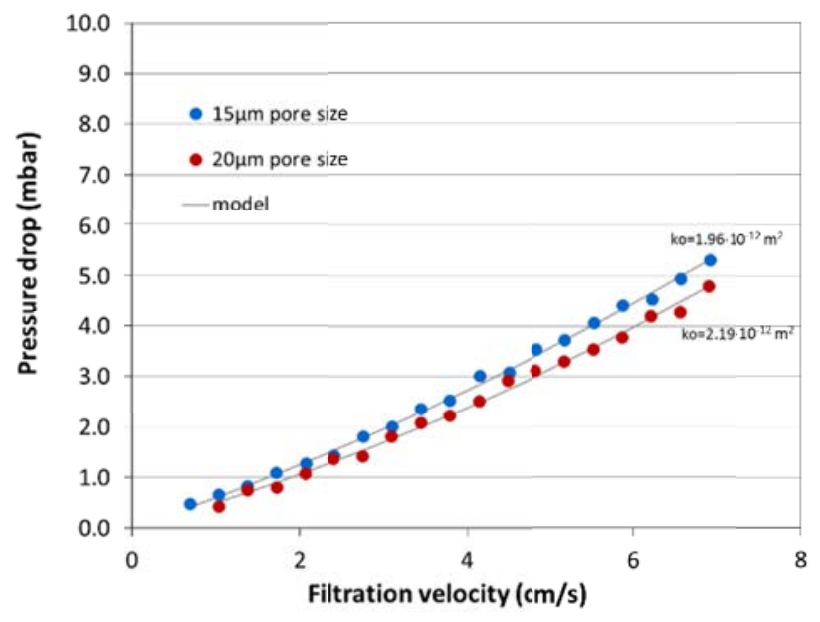

Fig. 9 - Flow resistance measurement for the case of the two different filters as a function of filtration velocity (points: experimental data, line: model).

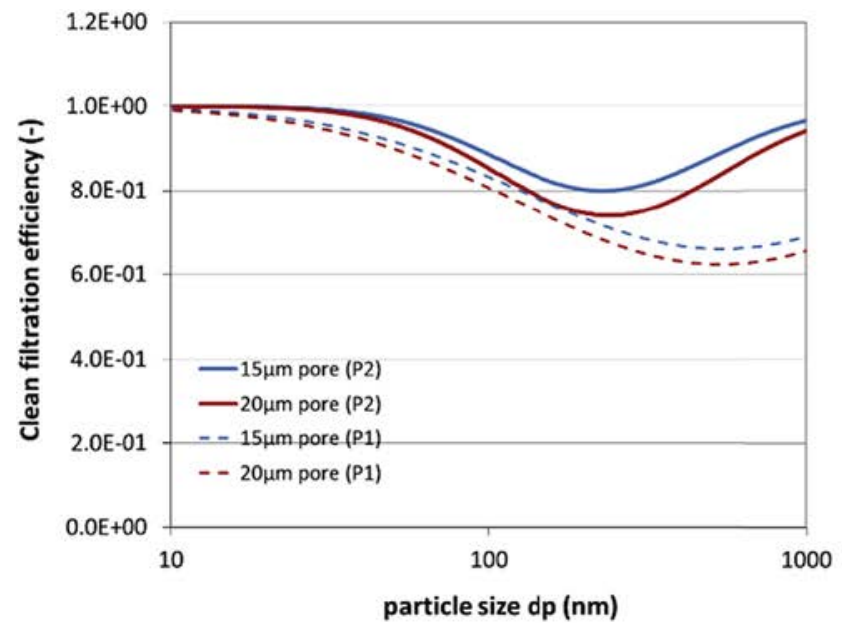

marked effect, with the larger grain size/higher porosity reaching quite low values of filtration efficiency, rendering this formulation inadequate for use without modification. The moderate effect of porosity on filtration efficiency can be seen mostly in the range of particle size attributed to the interception filtration mechanism (Fig. 8 (let)) while changing wall thickness (by a factor of $\approx 1.5$ ) is seen to have an even smaller effect but throughout the particle size spectrum (Fig. 8 (right)).

These parametric study results can guide the selection of the optimum wall material but can only do so conclusively after the development/design of the catalytic coating that must be added to the particle trap for reformate posttreatment. In the case of a thin uniform surface coating on the pore surfaces (i.e. coating thickness $<2 \mu \mathrm{m}$ ), the $17 \mu \mathrm{m}$ grain size at a porosity of $45 \%-50 \%$ (depending on final coating amount) will be optimum - the advantage in filtration efficiency from going to the small $(12 \mu \mathrm{m})$ grain size does not justify the pressure drop increase nor the risk of coating difficulty due to the smaller pore sizes. On the other hand, if the

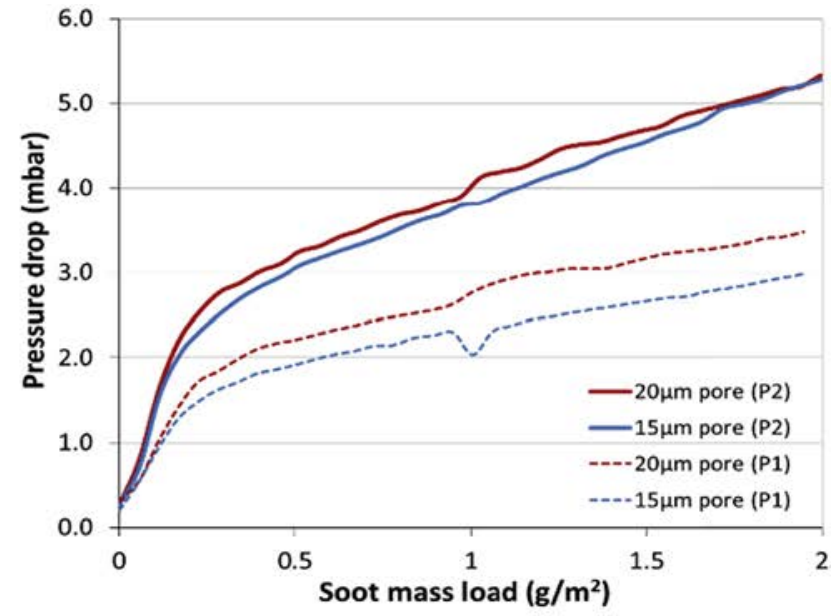

Fig. 10 - Filtration efficiency as a function of soot particle size for monoliths with different pore size (loading at two different CAST operating points corresponding to small $(91 \mathrm{~nm})$ and large (196 $\mathrm{nm}$ ) mean particle diameter (left) and pressure drop as a function of the soot deposit on (right) [42]. 


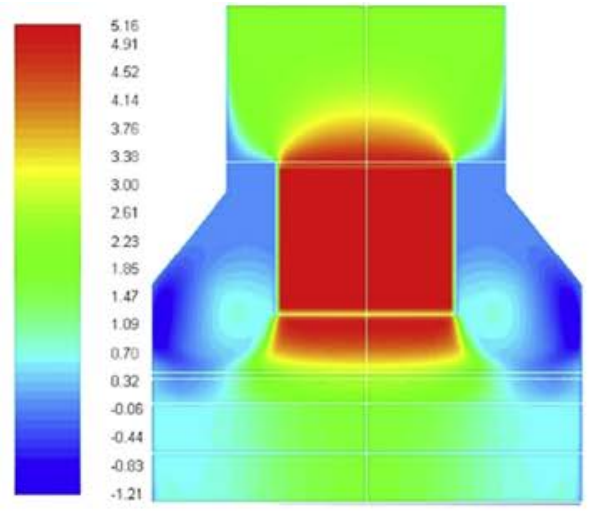

Case A: $ø 10 \mathrm{~mm}, \varphi=0.354$

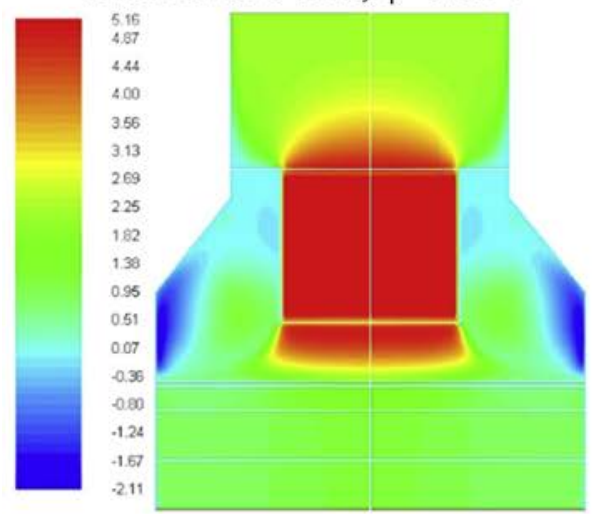

Case B: $ø 1 \mathrm{~mm}, \varphi=0.227$

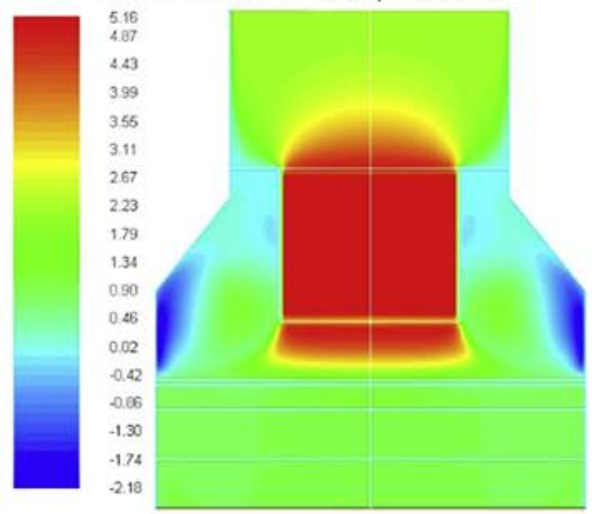

Case C: $\varnothing 0.5 \mathrm{~mm}, \varphi=0.19$

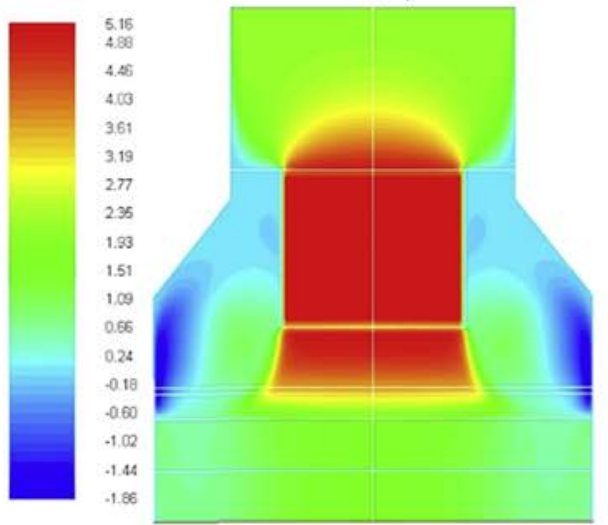

No distributor plate

(a)

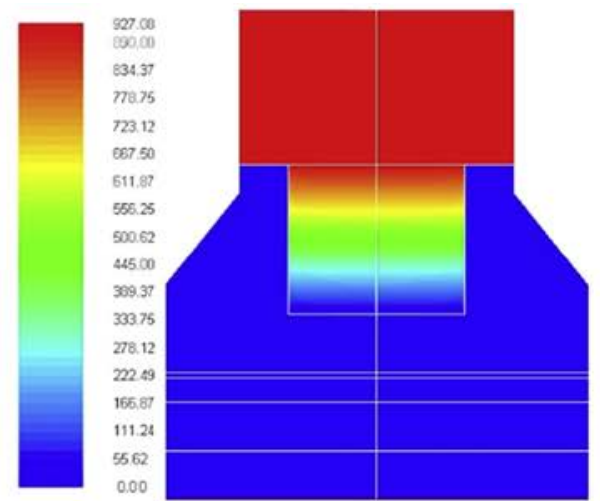

Case A: $ø 10 \mathrm{~mm}, \varphi=0.354$

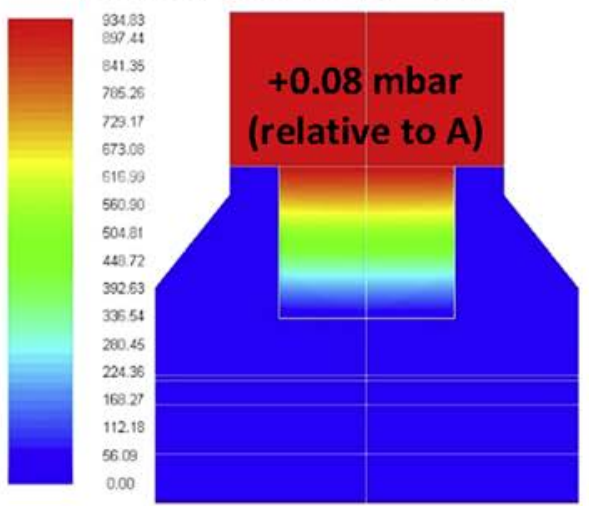

Case B: $ø 1 \mathrm{~mm}, \varphi=0.227$

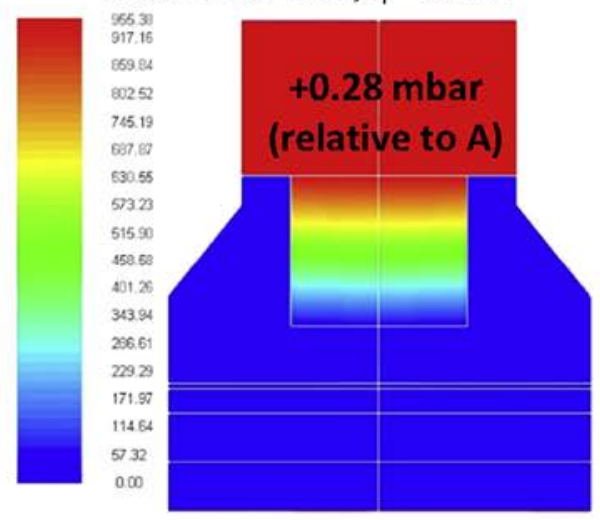

Case C: $\varnothing 0.5 \mathrm{~mm}, \varphi=0.19$
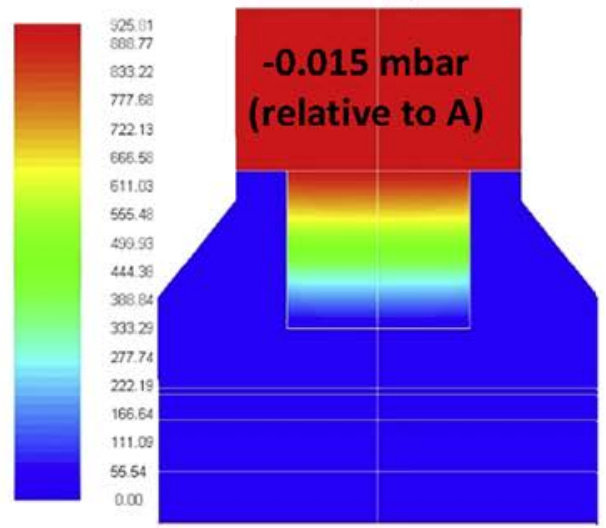

No distributor plate

(b)

Fig. 11 - Velocity contours colored by axial velocity [m/s] and pressure contours colored by static pressure [Pa] for the three distributor plate characteristics and for the case with no plate downstream of the filter. 
coating is coarser grained, then the resolved microstructure calculations indicate that the larger grain size $(24 \mu \mathrm{m})$ may be suitable, provided that the coating placed in the wall will modify the pore space in a way that will contribute to the otherwise low filtration efficiency for the larger $(>100 \mu \mathrm{m})$ mobility-equivalent diameter particles.

Based on the results of the study described above, two commercially available SiC monolithic honeycomb filter structures were selected that had 15 and $20 \mu \mathrm{m}$ mean pore size and $46 \%$ porosity. The filters were evaluated in terms of: i) flow resistance (permeability), ii) filtration efficiency and iii) development of pressure drop during loading of carbonaceous materials [42].

Regarding the flow resistance, the results showed that both monoliths develop the similar pressure drop as a function of the filtration velocity Fig. 9.

Also, both materials filter the smaller particles more effectively (Fig. 10 (left)) and, in both cases, the filtration efficiency quickly increases to $99 \%$ as soot particles accumulate on the monoliths.

Fig. 10 (right) shows the pressure drop during the particle loading. The initial pressure drop during particle loading is identical for the two monoliths in both operating points and originates from the similar initial permeability of the monoliths. The difference in the pressure drop developed between the two operating points is mainly caused by the change in the microstructural characteristics of the particle deposit (different particle sizes) [42].

\section{Integration of the wall-flow filter}

Fig. 11(a) depicts flow axial velocity contours obtained for each of the three cases investigated. For all cases, the flow from the reformate zone is subject to a sudden contraction before the gas mixture enters the soot filter zone due to its lower surface inlet. This is the region where the velocity gets its highest value, circa $u_{\text {axial }}=5.1 \mathrm{~m} / \mathrm{s}$. A stagnation/circulation zone is visible after the particle filter and off-center from the main flow, as evidence by regions with negative axial velocity. For Case A ( $\varnothing 10 \mathrm{~mm}$ holes in the distributor plate) the flow uniformity beneath the soot filter is poor; for the other Cases, B and $\mathrm{C}$, flow uniformity is improving as the plate's hole diameter decreases.

As seen in Fig. 11(b) from the pressure contours, the major part of pressure drop occurs because of the presence of the soot filter resulting to more than $900 \mathrm{~Pa}(9 \mathrm{mbar}$ ). Altering the plate's characteristics does not lead to a significant additional pressure drop, i.e. decreasing the hole diameter does not impose significant extra pressure drop penalty to the overall process. Case A (highest hole diameter case) presents the least overall pressure drop, but with poor velocity uniformity. Case B results in better flow uniformity with an additional 0.08 mbar pressure-drop penalty, while Case $C$ adds 0.28 mbar to the overall pressure drop relative to Case A. The smallest hole diameter considered provides adequate flow uniformity with insignificant pressure drop penalty and is therefore recommended for the filter integration. If no distributor plate was placed in the reactor's configuration there would be only minor differences in the flow profile while pressure drop is slightly lower compared with the plate with the larger holes (Case A $\varnothing 10 \mathrm{~mm}$ holes diameter).

The different cases can be directly compared in Fig. 12 (left) where the axial velocity at the inlet of the heat exchanger tubes is plotted. When considering a configuration without incorporating a distributor plate the velocity at the center of the reactor is 20 times that of the peripheral sites. While this case presents the smallest pressure drop the flow uniformity is the poorest. Even for the marginally effective $(\varnothing 10 \mathrm{~mm}$ holes) Case A uniformity is still poor but the axial velocity value at the center of the reactor is 4 times that of the peripheral sites. The transition to a distributor plate with a $\varnothing 1$ $\mathrm{mm}$ hole diameter (Case $\mathrm{B}$ ) brings the central flow velocity to 1.72 times that of the periphery. Case $C$ (the smallest hole diameter) presents the most uniform velocity profile, with the axial velocity value at reactor's center axis being 1.25 times that of the periphery.

For Case $C$ that presents the highest pressure drop, the pressure drop along the symmetry axis from the reformate zone to the heat exchanger tubes, exceeds $920 \mathrm{~Pa}(9.2 \mathrm{mbar}$ ) in the filter zone indicating that this is the dominating pressuredrop zone (Fig. 12 (right)). No observable pressure drop
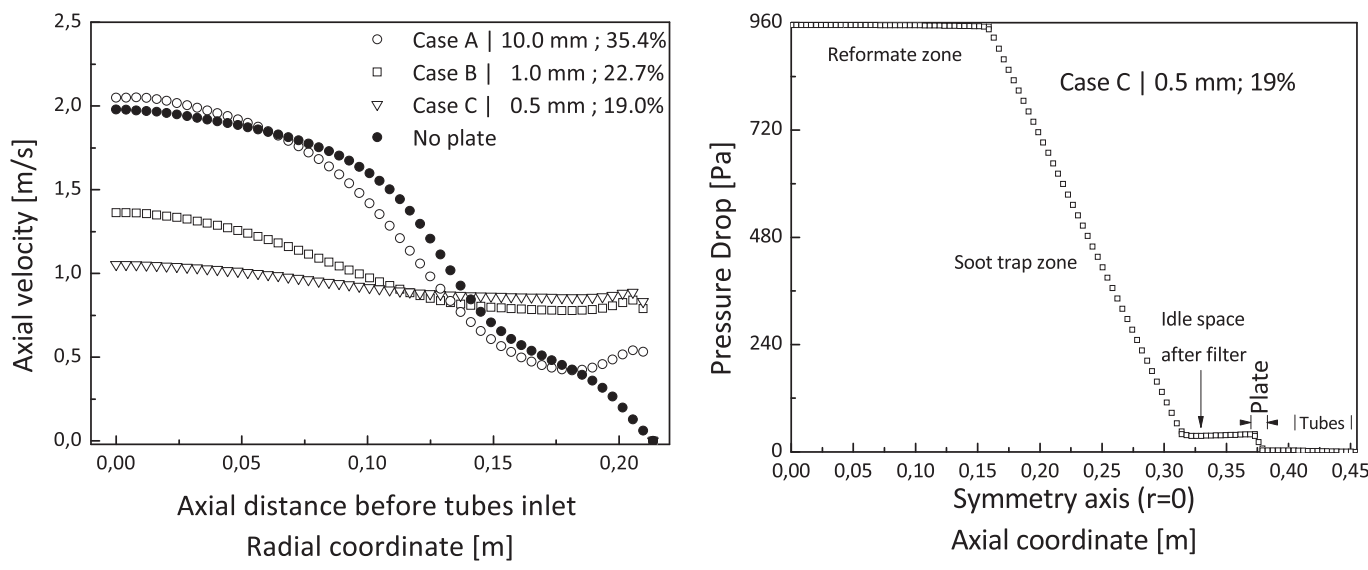

Fig. 12 - Axial velocity before tubes inlet with respect to the radial coordinate (left) and pressure drop along the symmetry axis with respect to the axial coordinate (right). 
(compared to the overall) takes place in the reformate zone and the idle space after the filter. The presence of the selected distributor plate (Case $\mathrm{C} \varnothing 0.5 \mathrm{~mm}$ ) adds $30 \mathrm{~Pa}(0.3 \mathrm{mbar}$ ) to the overall pressure drop.

Thus, the location of the filter downstream of the reactor will not create unacceptable backpressure to the ATR unit, however, it is found viable to add a distributor plate in the space downstream of the filter and upstream of the heat exchanger for improvement of flow uniformity at the inlet of the heat exchanger.

The plant testing to validate the simulation results are illustrated and discussed in the second part of this, which is related to the experimental campaign of the pre-commercial plant for $107 \mathrm{~kg} /$ day of hydrogen from biogas.

Hydrogen production from low carbon sources represents a valuable possibility to promote the decarbonisation of the energy system in a sustainable way and thus improve air quality [47]. The short-term challenge is to identify the paths leading to low-cost hydrogen production technologies with near zero greenhouse gas net emissions from highly efficient and diverse renewable sources [7]. In fact, in a LCA study performed also by the authors, it was demonstrated that the BioRobur technology presents a high-energy sustainability and a high efficiency, compared with biogas SR and biogas fueled IC engine followed by Alkaline Electrolyzer [43]. Moreover, regarding the market potential, BioRobur can play and important role because it can provide hydrogen from Municipal solid waste (MSW) at $5 € / \mathrm{kg} \mathrm{H}_{2}$ (delivered cost), cost within the European target [44].

\section{Conclusion}

A TRL 5 pre-commercial decentralized fuel processor for hydrogen production, based on the direct ATR of biogas was designed. The project promotes the development of sustainable technologies dedicated to a decentralized market. Particularly, the idea is to ensure the supply of clean, safe and reliable energy, in a competitive economic environment, reducing the effects of climate change and pollution, and addressing the question of exhaustion of oil reserves. The development of technologies like BioRobur for hydrogen production in the energy mix and the prospect of supplying "green" hydrogen for fuel-cell cars are expected to play a significant role in the European market.

Innovative cellular lattice supports were designed, and the results suggest a lattice composed of rotated cube cell as the most suitable catalyst support structure. Additionally, the investigating of the suitability of commercially available wallflow trap were performed. Based on the results of the study, two commercially available SiC monolithic honeycomb filter structures were selected that had 15 and $20 \mu \mathrm{m}$ mean pore size and $46 \%$ porosity. The integration of the wall-flow filter downstream of the ATR reactor was study, and the result has shown that its location does not creates a backpressure to the ATR unit, however, it is found viable to add a distributor plate in the space downstream of the filter and upstream of the heat exchanger for improvement of flow uniformity at the inlet of the heat exchanger.

\section{Acknowledgments}

The authors would like to thank the European commission for the financial support of this work in the Seventh Framework Programme project BioRobur under grant agreement $n^{\circ} 325383$.

\section{R E F E R E N C E S}

[1] Charisiou ND, Siakavelas G, Papageridis KN, Baklavaridis A, Tzounis L, Avraam DG, et al. Syngas production via the biogas dry reforming reaction over nickel supported on modified with $\mathrm{CeO}_{2}$ and/or $\mathrm{La}_{2} \mathrm{O}_{3}$ alumina catalysts. J Nat Gas Sci Eng 2016;31:164-83. http://dx.doi.org/10.1016/ j.jngse.2016.02.021.

[2] Goula MA, Charisiou ND, Papageridis KN, Delimitis A, Pachatouridou E, Iliopoulou EF. Nickel on alumina catalysts for the production of hydrogen rich mixtures via the biogas dry reforming reaction: influence of the synthesis method. Int J Hydrogen Energy 2015;40:9183-200. http://dx.doi.org/ 10.1016/j.ijhydene.2015.05.129.

[3] Hajjaji N, Martinez S, Trably E, Steyer J-P, Helias A. Life cycle assessment of hydrogen production from biogas reforming. Int J Hydrogen Energy 2016;41:6064-75. http://dx.doi.org/ 10.1016/j.ijhydene.2016.03.006.

[4] Hamedi MR, Tsolakis A, Lau CS. Biogas upgrading for onboard hydrogen production: reforming process CFD modelling. Int J Hydrogen Energy 2014;39:12532-40. http:// dx.doi.org/10.1016/j.jjhydene.2014.06.017.

[5] Galvagno A, Chiodo V, Urbani F, Freni F. Biogas as hydrogen source for fuel cell applications. Int J Hydrogen Energy 2013;38:3913-20. http://dx.doi.org/10.1016/ j.ijhydene.2013.01.083.

[6] Alves HJ, Bley Junior C, Niklevicz RR, Frigo EP, Frigo MS, Coimbra-Araújo $\mathrm{CH}$. Overview of hydrogen production technologies from biogas and the applications in fuel cells. Int J Hydrogen Energy 2013;38:5215-25. http://dx.doi.org/ 10.1016/j.ijhydene.2013.02.057.

[7] da Silva Veras T, Mozer TS, da Costa Rubim Messeder dos Santos D, da Silva César A. Hydrogen: trends, production and characterization of the main process worldwide. Int J Hydrogen Energy 2017;42:2018-33. http://dx.doi.org/10.1016/ j.ijhydene.2016.08.219.

[8] Pakhare D, Spivey J. A review of dry $\left(\mathrm{CO}_{2}\right)$ reforming of methane over noble metal catalysts. Chem Soc Rev 2014;43. http://dx.doi.org/10.1039/c3cs60395d.

[9] Kohn MP, Castaldi MJ, Farrauto RJ. Auto-thermal and dry reforming of landfill gas over a $\mathrm{Rh} / \mathrm{gAl}_{2} \mathrm{O}_{3}$ monolith catalyst. Appl Catal B Environ 2010;94:125-33. http://dx.doi.org/ 10.1016/j.apcatb.2009.10.029.

[10] Rostrup-Nielsen JR, Sehested J, Nørskov JK. Hydrogen and synthesis gas by steam- and $\mathrm{CO}_{2}$ reforming. Adv Catal 2002;47:65-139. http://dx.doi.org/10.1016/S0360-0564(02) 47006-X.

[11] Luneau M, Schuurman Y, Meunier FC, Mirodatos C, Guilhaume N. High-throughput assessment of catalyst stability during autothermal reforming of model biogas. Catal Sci Technol 2015;5:4390-7. http://dx.doi.org/10.1039/ C5CY00702J.

[12] Navarro RM, Peña MA, Fierro JLG. Hydrogen production reactions from carbon feedstocks: fossil fuels and biomass. Chem Rev 2007;107:3952-91. http://dx.doi.org/10.1021/ CR0501994.

[13] Ciambelli P, Palma V, Palo E. Comparison of ceramic honeycomb monolith and foam as Ni catalyst carrier for 
methane autothermal reforming. Catal Today 2010;155:92-100. http://dx.doi.org/10.1016/j.cattod.2009.01.021.

[14] Hijazi O, Munro S, Zerhusen B, Effenberger M. Review of life cycle assessment for biogas production in Europe. Renew Sustain Energy Rev 2016;54:1291-300. http://dx.doi.org/ 10.1016/j.rser.2015.10.013.

[15] Maestri M, Beretta A, Groppi G, Tronconi E, Forzatti P. Comparison among structured and packed-bed reactors for the catalytic partial oxidation of $\mathrm{CH}_{4}$ at short contact times. Catal Today 2005;105:709-17. http://dx.doi.org/10.1016/ j.cattod.2005.06.045.

[16] Richardson J, Garrait M, Hung J-K. Carbon dioxide reforming with $\mathrm{Rh}$ and $\mathrm{Pt}-\mathrm{Re}$ catalysts dispersed on ceramic foam supports. Appl Catal A Gen 2003;255:69-82. http://dx.doi.org/ 10.1016/S0926-860X(03)00645-8.

[17] Beretta A, Groppi G, Lualdi M, Tavazzi I, Forzatti P. Experimental and modeling analysis of methane partial oxidation: transient and steady-state behavior of Rh-coated honeycomb monoliths. Ind Eng Chem Res 2009;48:3825-36. http://dx.doi.org/10.1021/ie8017143.

[18] Sang L, Sun B, Tan H, Du C, Wu Y, Ma C. Catalytic reforming of methane with $\mathrm{CO}_{2}$ over metal foam based monolithic catalysts. Int J Hydrogen Energy 2012;37:13037-43. http:// dx.doi.org/10.1016/j.ijhydene.2012.05.056.

[19] Palma V, Ricca A, Ciambelli P. Structured catalysts for methane auto-thermal reforming in a compact thermal integrated reaction system. Appl Therm Eng 2013;61:128-33. http://dx.doi.org/10.1016/j.applthermaleng. 2013.03.038

[20] Palma V, Palo E, Ciambelli P. Structured catalytic substrates with radial configurations for the intensification of the WGS stage in $\mathrm{H}_{2}$ production. Catal Today 2009;147:S107-12. http:// dx.doi.org/10.1016/j.cattod.2009.07.047.

[21] Vincenzo Palma, Ricca Antonio CP. Structured catalysts for methane auto-thermal reforming in a compact thermal integrated ATR reformer. Chem Eng Trans 2012;29. http:// dx.doi.org/10.3303/CET1229270.

[22] Li C, Xu H, Hou S, Sun J, Meng F, Ma J, et al. SiC foam monolith catalyst for pressurized adiabatic methane reforming. Appl Energy 2013;107:297-303. http://dx.doi.org/ 10.1016/j.apenergy.2013.02.039.

[23] García-Vargas JM, Valverde JL, de Lucas-Consuegra A, Gómez-Monedero B, Sánchez P, Dorado F. Precursor influence and catalytic behaviour of $\mathrm{Ni} / \mathrm{CeO}_{2}$ and $\mathrm{Ni} / \mathrm{SiC}$ catalysts for the tri-reforming process. Appl Catal A Gen 2012;431:49-56. http://dx.doi.org/10.1016/ j.apcata.2012.04.016.

[24] Mach FRA, Issendorff FV, Delgado A, Ortona A. Experimental investigation of the oxidation behaviour of SiSiC foams. In: Narayan R, Colombo P, editors. Adv. Bioceram. Porous Ceram. Ceram. Eng. Sci. Proc, vol. 29. Hoboken, NJ, USA: John Wiley \& Sons, Inc; 2009. p. 299-311. http://dx.doi.org/ 10.1002/9780470456262.ch26.

[25] Ortona A, D'Angelo C, Gianella S, Gaia D. Cellular ceramics produced by rapid prototyping and replication. Mater Lett 2012;80:95-8. http://dx.doi.org/10.1016/j.matlet.2012.04.050.

[26] Rezaei E, Haussener S, Gianella S, Ortona A. Early-stage oxidation behavior at high temperatures of SiSiC cellular architectures in a porous burner. Ceram Int 2016;42:16255-61. http://dx.doi.org/10.1016/j.ceramint.2016.07.159.

[27] Konstandopoulos AG, Kostoglou M, Skaperdas E, Papaioannou E, Zarvalis D, Kladopoulou E. Fundamental studies of diesel particulate filters: transient loading, regeneration and aging, SAE Tech Pap No 2000-01-1016, SAE SP, 1940. Diesel Exhaust Aftertreatment 2000. http:// dx.doi.org/10.4271/2000-01-1016.

[28] Fino D, Bensaid S, Piumetti M, Russo N. A review on the catalytic combustion of soot in diesel particulate filters for automotive applications: from powder catalysts to structured reactors. Appl Catal A Gen 2016;509:75-96. http:// dx.doi.org/10.1016/j.apcata.2015.10.016.

[29] Karadimitra K, Lorentzou S, Agrafiotis C, Konstandopoulos AG. Catalytic particle synthesis via aerosol spray pyrolysis and in-situ deposition on porous filter materials. PARTEC 2004 Int Congr Part Technol 2004.

[30] Simpson AP, Lutz AE. Exergy analysis of hydrogen production via steam methane reforming. Int J Hydrogen Energy 2007;32:4811-20. http://dx.doi.org/10.1016/ j.ijhydene.2007.08.025.

[31] Manenti F, Pelosato R, Vallevi P, Leon-Garzon AR, Dotelli G, Vita A, et al. Biogas-fed solid oxide fuel cell (SOFC) coupled to tri-reforming process: modelling and simulation. Int $\mathrm{J}$ Hydrogen Energy 2015;40:14640-50. http://dx.doi.org/ 10.1016/j.ijhydene.2015.08.055.

[32] Laurinat M. Investigation of different grid geometries for additively manufactured supports of a catalyst for biogas reforming on the basis of CFD simulations. TU Freiberg; 2014.

[33] Mendes M, Ray S, Trimis DA. Simple and efficient method for the evaluation of effective thermal conductivity of open-cell foam-like structures. Int J Heat Mass Transf 2013;66:412-22.

[34] Mendes M, Asad A, Gotze P, Werzner E, Wulf R, Trimis D, et al. Sensitivity analysis of effective thermal conductivity of open-cell ceramic foams using a simplified model based on detailed structure. In: 5th int conf porous media their appl sci eng ind; 2014.

[35] Yu D, Mei R, Luo S, Shyy W. Viscous flow computations with the method of lattice Boltzmann equation. Prog Aerosp Sci 2003:39:329-67.

[36] Aidun C, Clausen J. Lattice-Boltzmann method for complex flows. Annu Rev Fluid Mech 2010;42:439-72.

[37] Herrmann Andreas, Pönisch M, Werzner E, Laurinat M, Rezaei E, Ortona A, et al. Development of an autothermal biogas processor for hydrogen production. In: Int gas union res conf 2014; 2014.

[38] Vlachos ND, Konstandopoulos AG. Digital materials methods for DPF development. SAE Tech Pap No 2006-01-0260 2006.

[39] Konstandopoulos AG, Kostoglou M, Vlachos N, Kladopoulou E. Progress in diesel particulate filter simulation. SAE Tech Pap No 2005-01-0946, SAE SP, 1940 Diesel Exhaust Emiss Control Model 2005:11-40. http:// dx.doi.org/10.4271/2005-01-0946.

[40] Chorin AJ. A numerical method for solving incompressible viscous flow problems. J Comput Phys 1967:12-26.

[41] Konstandopoulos AG. Flow resistance descriptors for diesel particulate filters: definitions, measurements and testing, SAE Tech Pap No 2003-01-0846, SAE SP, 1755. Diesel Emis Meas Model 2003:249-61. http://dx.doi.org/10.4271/2003-01-0846.

[42] Montenegro Camacho YS, Bensaid S, Fino D, Trimis D, Herrmann A, Guilhaume N, et al. Biogas robust processing with combined catalytic reformer and trap: BioRobur project. WIT Trans Ecol Environ 2015;195:463-74. http://dx.doi.org/ 10.2495/ESUS150391. WIT Press.

[43] Battista F, Montenegro Camacho YS, Hernández S, Bensaid S, Herrmann A, Krause $\mathrm{H}$, et al. LCA evaluation for the hydrogen production from biogas through the innovative BioRobur project concept. Int J Hydrogen Energy 2017;42:14030-43. http://dx.doi.org/10.1016/ j.ijhydene.2016.12.065.

[44] Montenegro Camacho YS, Bensaid S, Piras G, Antonini M, Fino D. Techno-economic analysis of green hydrogen production from biogas autothermal reforming. Clean Technol Environ Policy 2017:1-11. http://dx.doi.org/10.1007/ s10098-017-1341-1.

[45] Wei Q, Yang G, Yoneyama Y, Vitidsant T, Tsubaki N. Designing a novel $\mathrm{Ni}-\mathrm{Al}_{2} \mathrm{O}_{3}-\mathrm{SiC}$ catalyst with a stereo 
structure for the combined methane conversion process to effectively produce syngas. Catal Today 2016;265:36-44. http://dx.doi.org/10.1016/j.cattod.2015.08.029.

[46] Ricca A, Palma V, Martino M, Meloni E. Innovative catalyst design for methane steam reforming intensification. Fuel 2017;198:175-82. http://dx.doi.org/10.1016/j.fuel.2016.11.006.
[47] Chiodo V, Urbani F, Galvagno A, Mondello N, Freni S. Analysis of biogas reforming process for molten carbonate fuel cells. J Power Sources 2012;206:215-21. http://dx.doi.org/ 10.1016/j.jpowsour.2012.01.114. 